\title{
KEPUASAN KERJA SEBAGAI MODERASI PENGARUH TOTAL QUALITY MANAGEMENT TERHADAP KINERJA KARYAWAN
}

\author{
Dessy Ekaviana ${ }^{1}$, David Kaluge ${ }^{1}$ \\ ${ }^{1}$ Jurusan Akuntansi, Fakultas Ekonomi dan Bisnis, Universitas Brawijaya \\ Malang \\ dekanprasetya@gmail.com \\ davidkaluge@gmail.com
}

\begin{abstract}
This research was conducted to determine the effect of Total Quality Management on Employee Performance with a moderating variable namely Job Satisfaction. The method used in this study is regression analysis. The conclusions from the results of data analysis are (1) Total Quality Management has a significant effect on Employee Performance so that by increasing the value of Total Quality Management (TQM) it will provide a significant increase in Employee Performance. (2) Total Quality Management and Job Satisfaction show insignificant influence on Employee Performance, so the hypothesis that Job Satisfaction moderates the relationship between Total Quality Management and Employee Performance is rejected because the effect is insignificant.
\end{abstract}

Keywords: Job Satisfaction; Employee Performance; Total Quality Management

\begin{abstract}
ABSTRAK
Penelitian ini dilakukan untuk mengetahui pengaruh Total Quality Management terhadap Kinerja Karyawan dengan variabel moderating yaitu Kepuasan Kerja. Metode yang digunakan pada penelitian ini adalah analisis regresi. Adapun kesimpulan dari hasil analisis data adalah (1) Total Quality Management mempunyai pengaruh yang signifikan terhadap Kinerja Karyawan sehingga dengan semakin meningkatkan nilai Total Quality Management (TQM) maka akan memberikan peningkatan yang signifikan terhadap Kinerja Karyawan. (2) Total Quality Management dan Kepuasan Kerja menunjukkan pengaruh yang tidak signifikan terhadap Kinerja Karyawan, maka hipotesis yang menyatakan bahwa Kepuasan Kerja memoderasi terhadap hubungan antara Total Quality Management dan Kinerja Karyawan adalah semu karena pengaruhnya tidak signifikan.
\end{abstract}

Kata Kunci: Kepuasan Kerja; Kinerja Karyawan; Total Quality Management
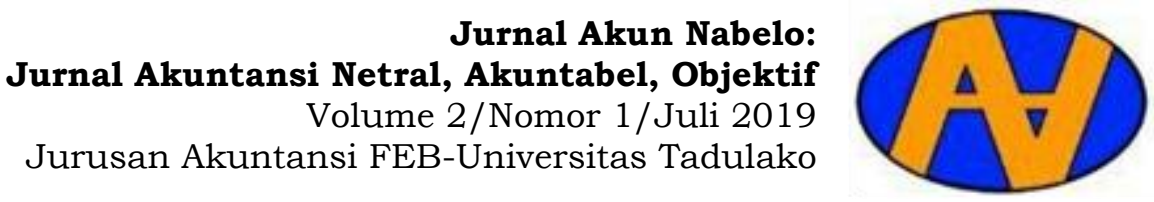


\section{A. PENDAHULUAN}

Pada era perkembangan teknologi dan informasi saat ini, dunia bisnis setidaknya menghadapi tiga tantangan besar, yakni pelanggan yang berorientasi pada kualitas produk dengan harga yang terjangkau, persaingan yang semakin ketat antar perusahaan, dan adanya perubahan (change) yang menuntut perusahaan untuk berani melakukan terobosan dan inovasi baru untuk memenangkan persaingan bisnis. Salah sumber daya paling penting dalam perusahaan adalah sumber daya manusia. Kualitas sumber daya manusia dapat mempengaruhi hasil kinerja suatu perusahaan, sehingga strategi dalam mengelola sumber daya manusia merupakan bagian dari strategi bisnis (Satyawati \& Suartana, 2014). Kondisi ini yang mendorong perusahaan untuk lebih fokus pada aspek perencanaan dan pengendalian pada faktor manusia.

Meningkatkan kinerja karyawannya, perusahaan harus menerapkan sistem manajemen yang baik, yang dapat dijadikan sebagai alat untuk meningkatkan kinerja perusahaan. Salah satu alat manajemen kualitas yang dapat digunakan adalah Total Quality Management (TQM) (Pratama \& Maghfiroh, 2018). TQM merupakan sebuah konsep yang digunakan oleh organisasi untuk mempertahankan keunggulan bersaing dan memastikan efektivitas operasional perusahaan (ALNasser, Yusoff, \& Islam, 2013; Chang, Chiu, \& Chen, 2010). Penerapan TQM dilakukan sebagai salah satu strategi perusahaan dalam menghasilkan kinerja pelayanan yang baik, sehingga pelaksanaannya berorientasi pada kepuasan pelanggan dan melibatkan seluruh anggota perusahaan termasuk karyawan (Eddy, 2006). Dari sini, dapat dikatakan bahwa praktik TQM ditujukan untuk melakukan perbaikan secara berkesinambungan atau terus-menerus terhadap produk atau jasa, sumber daya manusia, proses dan lingkungannya, sehingga bisa menghasilkan kualitas yang terbaik dan unggul dalam persaingan.

Terkait dengan kinerja karyawan, pada dasarnya penerapan TQM yang dilakukan secara terencana dan terarah diharapkan dapat membantu dalam peningkatan produktivitas dan kinerja karyawan (Eddy, 2006). Semakin sering suatu perusahaan melakukan pengukuran kinerja karyawan, maka perusahaan akan lebih meningkatkan kinerja karyawannya, dan peningkatan kinerja tersebut akan berdampak pada peningkatan mutu perusahaan. Hasil kajian empiris mengenai peran TQM terhadap peningkatan kinerja karyawan bervariasi. (Joiner, 2007) dan (Al-Shobaki, Fouad, \& Al-Bashir, 2010) menemukan bahwa TQM berpengaruh positif, sementara penelitian (Enny W., 2015) menemukan bahwa TQM tidak memiliki pengaruh positif signifikan terhadap kinerja karyawan.

Selain bertujuan untuk meningkatkan kinerja organisasi melalui kinerja karyawannya, efektivitas penerapan TQM juga dapat mendorong perasaan afektif seseorang dalam pekerjaannya. Dalam hal ini, TQM sebagai sistem manajemen mutu yang berorientasi pada kualitas produk dan jasa, mempunyai tujuan akhir yakni mencapai kepuasan pelanggan (Efendi \& Mandala, 2018). Seperti yang dinyatakan oleh (Akdere, 2009) bahwa terdapat hubungan positif yang kuat antara kepuasan pelanggan dan kepuasan kerja karyawan. Hal ini memberikan implikasi bahwa kepuasan pelanggan, sebagai tujuan dari manajemen mutu, dapat dicapai melalui kepuasan kerja karyawan (Schroeder, Linderman, \& Zhang, 2010). (Alsughayir, 2014; Chang et al., 2010; Ooi, Lin, Tan, \& Chong, 2011) menemukan bahwa TQM memiliki pengaruh yang positif terhadap kepuasan kerja karyawan. Di sisi lain, (Prasanti \& Damayanti, 2018) telah menemukan bahwa tidak ada hubungan yang signifikan antara manajemen mutu perusahaan dengan kepuasan kerja karyawan. Adanya pandangan negatif dari implementasi manajemen mutu melalui pendekatan kreatif, dapat menghasilkan variasi pekerjaan dan kepuasan kerja yang rendah.

Kepuasan kerja tidak hanya merupakan dimensi penting atas kesejahteraan karyawan, tetapi juga merupakan indikator yang diperlukan dalam mencapai keberhasilan organisasi (Culbertson, 2011). Hal ini sesuai dengan (Pritchard \& Karasick, 1973) yang mengatakan bahwa kepuasan kerja menjadi salah faktor yang sangat penting dalam mencapai keberhasilan organisasi. (Chang et al., 2010) mengemukakan bahwa kepuasan karyawan 
merupakan nilai sebuah perusahaan, yang pada waktunya akan meningkatkan kualitas layanan dan produktivitas. Dalam hal ini, program TQM ditujukan untuk menghasilkan peningkatan produktivitas yang signifikan dalam jangka panjang (Kamal \& Sengupta, 2008), sedangkan kepuasan kerja diarahkan untuk memperluas upaya peningkatan prestasi kerja, yang kemudian akan menjadikan karyawan bekerja lebih keras dan lebih baik (Pushpakumari, 2008). Penelitian (Khan, Nawaz, Aleem, \& Hamed, 2012) menemukan bahwa kepuasan kerja berpengaruh positif terhadap kinerja karyawan itu sendiri. Sebaliknya, (Hameed, Ramzan, kashif zubair, Ali, \& Arslan, 2014) telah menemukan bahwa salary, reward, dan indirect compensation sebagai indikator kepuasan kerja, tidak berpengaruh signifikan terhadap kinerja karyawan.

Mengacu pada beberapa hasil temuan penelitian sebelumnya, dapat disinyalir bahwa praktik TQM pada dasarnya dapat memberikan dampak kepada tingkat kepuasan kerja dan kinerja karyawan dalam suatu perusahaan. Adanya hasil yang tidak konsisten dari temuan penelitian tersebut, melatarbelakangi peneliti untuk mengkaji kembali model TQM terhadap kinerja karyawan dengan mempertimbangkan peran moderasi dari kepuasan kerja. Permasalahan ini menjadi menarik untuk diangkat dan dikaji kembali mengingat dinamika praktik TQM dan perubahan yang telah terjadi, sehingga diharapkan dapat memberikan gambaran baru secara lebih komprehensif mengenai pola hubungan TQM dan kinerja karyawan melalui peran moderasi kepuasan kerja.

\section{B. METODE PENELITIAN}

Penelitian ini dirancang sebagai salah satu penelitian empiris yang menguji hipotesis dengan menggunakan metode kausalitas dengan menggunakan pendekatan positivist. Penelitian ini membatasi pada permasalahan pengaruh implementasi Total Quality Management (TQM) sebagai variabel independen, kinerja manajerial sebagai variabel dependen, serta kepuasan kerja sebagai variabel moderating.

Total Quality Management (TQM) (X1). TQM merupakan suatu cara untuk melakukan perbaikan secara terus menerus pada setiap level operasi atau proses dan pada setiap area fungsional, dengan menggunakan sumberdaya manusia dan modal yang tersedia. Adapun indikator pengukuran yang dikembangkan oleh (Ooi, Bakar, Arumugam, Vellapan, \& Loke, 2007) meliputi:

(1) Reward atau penghargaan, (2) Fokus pada pelanggan, (3) Budaya organisasi, (4) Kepercayaan organisasi, dan (5) Kerjasama tim.

Kepuasan Kerja (X2). Kepuasan kerja merupakan suatu keadaan emosi karyawan dalam merasakan keadaan yang menyenangkan yang dihubungkan dengan berbagai macam faktor atau dimensi dari tugas-tugas dalam pekerjaannya. Adapun indikator pengukuran yang dikembangkan oleh (Ooi et al., 2007) meliputi: (1) Rekan kerja, (2) Supervisi, (3) Gaji, dan (4) Kesempatan promosi.

Kinerja Karyawan (Y). Kinerja karyawan merupakan suatu hasil kerja yang dicapai seseorang dalam melaksanakan penugasan yang dibebankan kepadanya, baik secara kualitas maupun kuantitas yang dilakukan selama periode tertentu. Adapun indikator pengukuran yang dikembangkan oleh (Putu, Juana, Sudibya, \& Sintaasih, 2016) meliputi: (1) kualitas kerja, (2) kuantitas kerja, dan (3) ketepatan waktu.

Objek dalam penelitian ini adalah karyawan bidang usaha jasa perhotelan dengan kategori bintang 4 dan 5 di Kota Malang. Latar belakang peneliti memilih perusahaan jasa sebagai objek penelitian karena dalam perkembangan global ini menuntut tidak hanya produk berupa barang yang harus diperhatikan kualitasnya namun produk jasa juga menarik untuk diteliti. Penelitian dilakukan selama 3 (tiga) bulan pada awal tahun dikarenakan sebagian besar usaha jasa perhotelan mengalami low-season pada waktu tersebut, sehingga besaran data yang terkumpul akan sesuai dengan harapan peneliti.

Teknik Metode sampel yang digunakan dalam penelitian ini adalah probability sampling, sedangkan teknik pengambilan sampel yang digunakan adalah simple random sampling. Pemilihan teknik ini didasarkan pada 
penyebaran anggota populasi yang tidak terlalu luas secara geografis dan karakteristik populasi yang cukup homogen, yang secara keseluruhan diambil melalui unit yang sama yaitu karyawan middle-up level.

Peneliti mengumpulkan data dan informasi yang diperlukan dalam penelitian ini dengan metode pengumpulan data berupa penelitian lapangan. Pada penelitian ini, yang menjadi subyek penelitian adalah karyawan perhotelan dari berbagai divisi (level supervisor, assistant manager dan manager) dan dilakukan dengan penyebaran kuesioner mengenai implementasi TQM, kepuasan kerja, dan kinerja perusahaan dengan teknik personally administered questionnaires.

Metode analisis data menggunakan statistik deskriptif, uji kualitas data, uji asumsi klasik dan uji hipotesis dengan bantuan komputer melalui program IBM SPSS 21 for Windows.

\section{HASIL DAN PEMBAHASAN}

\section{C.1. Hasil Analisis Regresi Linier Berganda}

Analisis regresi ini digunakan untuk menghitung besarnya pengaruh antara variabel bebas, yaitu Total Quality Management (X1), Kepuasan Kerja (X2), Total Quality Management*Kepuasan Kerja $\left(\mathrm{X} 1{ }^{*} \mathrm{X} 2\right)$ terhadap variabel terikat yaitu Kinerja Karyawan (Y). Persamaan regresi digunakan mengetahui bentuk hubungan antara variabel bebas dengan variabel terikat. Dengan menggunakan bantuan SPSS for Windows ver 21.00 didapat modelregresi seperti pada Tabel 1.

Tabel 1

Persamaan Regresi

\begin{tabular}{|c|cc|c|c|c|}
\hline & \multicolumn{2}{|c|}{$\begin{array}{c}\text { Unstandardized } \\
\text { Coefficients }\end{array}$} & \multirow{2}{*}{$\begin{array}{c}\text { Standardized } \\
\text { Coefficients }\end{array}$} & $\mathrm{t}$ & Sig. \\
\cline { 2 - 3 } & $\mathrm{B}$ & Std. Error & & & \\
\hline (Constant) & 11.873 & 5.477 & & 2.168 & 0.037 \\
X1 & 0.305 & 0.071 & 0.585 & 4.272 & 0.000 \\
(Constant) & 40.830 & 32.146 & & 1.270 & 0.213 \\
X1 & -0.557 & 0.465 & -1.070 & -1.199 & 0.239 \\
\hline
\end{tabular}

Berdasarkan Tabel 1, didapatkan persamaan regresi sebagai berikut:

$$
\mathrm{Y}=11,873+0,305 \mathrm{X} 1
$$

$$
\mathrm{Y}=40,830-0,557 \mathrm{X} 1+0,027 \mathrm{X} 2+0,010 \mathrm{X} 1 \mathrm{X} 2
$$

Dari persamaan di atas dapat diinterpretasikan sebagai berikut:

1. Kinerja Karyawan akan meningkat sebesar 0,305 satuan untuk setiap tambahan satu satuan X1 (Total Quality Management). Jadi apabila Total Quality Management mengalami peningkatan 1 satuan, maka Kinerja Karyawan akan meningkat sebesar 0,305 satuan dengan asumsi variabel yang lainnya dianggap konstan.

2. Kinerja Karyawan akan meningkat sebesar 0,001 satuan untuk setiap tambahan satu satuan X1X2 (Total Quality Management*Kepuasan Kerja). Jadi Total Quality Management*Kepuasan Kerja dapat memperkuat hubungan antara Total Quality Management dengan Kinerja Karyawan.

\section{C.2. Koefisien Determinasi (R2)}

Untuk mengetahui besar kontribusi variabel bebas (Total Quality Management (X1), Kepuasan Kerja (X2), dan Total Quality Management*Kepuasan Kerja (X1X2)) terhadap variabel terikat (Kinerja Karyawan) digunakan nilai R2,nilai R2 seperti dalam Tabel 2 di bawah ini.

Tabel 2

Koefisien Determinasi

$\begin{array}{ccc}R & \begin{array}{c}\mathrm{R} \\ \text { Square }\end{array} & \begin{array}{c}\text { Adjusted } \mathrm{R} \\ \text { Square }\end{array} \\ 0.585 & 0.343 & 0.324 \\ 0.821 & 0.674 & 0.644\end{array}$


Koefisien determinasi digunakan untuk menghitung besarnya pengaruh atau kontribusi variabel bebas terhadap variabel terikat. Dari analisis pada Tabel 2 diperoleh hasil adjusted R2 (koefisien determinasi) sebesar 0,644. Artinya bahwa 64,4\% variabel Kinerja Karyawan akan dipengaruhi oleh variabel bebasnya, yaitu Total Quality Management(X1), Kepuasan Kerja (X2), dan Total Quality Management*Kepuasan Kerja (X1X2). Sedangkan sisanya 35,6\% variabel Kinerja Karyawan akan dipengaruhi oleh variabel-variabel yang lain yang tidak dibahas dalam penelitian ini.

Selain koefisien determinasi juga didapat koefisien korelasi yang menunjukkan besarnya hubungan antara variabel bebas yaitu Total Quality Management, Kepuasan Kerja, dan Total Quality Management*Kepuasan Kerja dengan variabel Kinerja Karyawan, nilai R (koefisien korelasi) sebesar 0.821, nilai korelasi ini menunjukkan bahwa hubungan antara variabel bebas yaitu Total Quality Management (X1), Kepuasan Kerja (X2), dan Total Quality Management*Kepuasan Kerja (X1X2) dengan Kinerja Karyawan termasuk dalam kategori sangat kuat karena berada pada selang 0,8- 1 .

\section{C.3. Hasil Pengujian Hipotesis}

Pengujian $\mathrm{F}$ atau pengujian model digunakan untuk mengetahui apakah hasil dari analisis regresi signifikan atau tidak, dengan kata lain model yang diduga tepat/sesuai atau tidak. Jika hasilnya signfikan, maka HO ditolak dan H1 diterima. Sedangkan jika hasilnya tidak signifikan, maka HO diterima dan H1 ditolak. Hal ini dapat juga dikatakan sebagai berikut.

Tabel 3

Uji F

\begin{tabular}{cccccc} 
& Sum of Squares & df & Mean Square & $F$ & Sig. \\
\cline { 2 - 5 } Regression & 323.7494 & 1 & 323.749 & 18.247 & 0.000 \\
Residual & 621.0074 & 35 & 17.743 & & \\
Total & 944.7568 & 36 & & & \\
Regression & 636.7441 & 3 & 212.248 & 22.740 & 0.000 \\
Residual & 308.0126 & 33 & 9.334 & & \\
Total & 944.7568 & 36 & & &
\end{tabular}

Berdasarkan Tabel 3 nilai $\mathrm{F}$ hitung sebesar 22,741. Sedangkan $\mathrm{F}$ tabel $(\mathrm{a}=$ 0.05 ; db regresi $3: \mathrm{db}$ residual $=33$ ) adalah sebesar 2,891. Karena $\mathrm{F}$ hitung $>\mathrm{F}$ tabel yaitu $22,740>2,891$ atau nilai sig $\mathrm{F}(0,000)<\mathrm{a}=0.05$ maka model analisis regresi adalah signifikan. Hal ini berarti HO ditolak dan $\mathrm{H} 1$ diterima sehingga dapat disimpulkan bahwa variabel terikat (Kinerja Karyawan) dapat dipengaruhi secara signifikan oleh variabel bebas (Total Quality Management (X1), Kepuasan Kerja (X2), dan Total Quality Management*Kepuasan Kerja $(\mathrm{X} 1 * \mathrm{X} 2)$

$\mathrm{T}$ test digunakan untuk mengetahui apakah masing-masing variabel bebas secara parsial mempunyai pengaruh yang signifikan terhadap variabel terikat. Dapat juga dikatakan jika $\mathrm{t}$ hitung $>\mathrm{t}$ tabel atau - $\mathrm{t}$ hitung $<-\mathrm{t}$ tabel maka hasilnya signifikan dan berarti HO ditolak dan $\mathrm{H} 1$ diterima. Sedangkan jika $t$ hitung $<\mathrm{t}$ tabel atau -t hitung > -t tabel maka hasilnya tidak signifikan dan berarti HO diteima dan H1ditolak. Hasil dari uji t dapat dilihat pada Tabel 4.

Tabel 4

Hasil Uji t

\begin{tabular}{|c|c|c|c|}
\hline $\mathrm{t}$ & & & Sig. \\
\hline (Constant) & 2.168 & & 0.037 \\
\hline $\mathrm{X} 1$ & & 4.272 & 0.000 \\
\hline (Constant) & 1.270 & & 0.213 \\
\hline $\mathrm{X} 1$ & & -1.199 & 0.239 \\
\hline $\mathrm{X} 2$ & & 0.037 & 0.971 \\
\hline $\mathrm{X} 1 \mathrm{X} 2$ & & 0.973 & 0.338 \\
\hline
\end{tabular}


Berdasarkan Tabel 4 diperoleh hasil sebagai berikut. t test antara X1 (Total Quality Management) dengan $\mathrm{Y}$ (Kinerja Karyawan) menunjukkan $\mathrm{t}$ hitung = 4,272. Sedangkan t tabel $(a=0.05 ; d b$ residual $=33$ ) adalah sebesar 2,034. Karena $t$ hitung $>\mathrm{t}$ tabel yaitu 4,272 $>2,034$ atau nilai sig $\mathrm{t}(0,000)<\mathrm{a}=0.05$ maka pengaruh X1 (Total Quality Management) terhadap Kinerja Karyawan adalah signifikan. Hal ini berarti HO ditolak dan H1 diterima sehingga dapat disimpulkan bahwa Kinerja Karyawan dapat dipengaruhi secara signifikan oleh Total Quality Management atau dengan meningkatkan Total Quality Management maka KinerjaKaryawan akan mengalami peningkatan secara nyata.

t test antara X1X2 (Total Quality Management*Kepuasan Kerja) dengan Y (Kinerja Karyawan) menunjukkan $t$ hitung $=0,973$. Sedangkan $t$ tabel $(a=0.05$; $\mathrm{db}$ residual $=33$ ) adalah sebesar 2,034. Karena t hitung $<\mathrm{t}$ tabel yaitu $0,973<$ 2,034 atau nilai sig t $(0,338)>a=0.05$ maka pengaruh X1X2 (Total Quality Management*Kepuasan Kerja) terhadap Kinerja Karyawan adalah tidak signifikan pada alpha $5 \%$. Hal ini berarti Ho diterima sehingga dapat disimpulkan bahwa Kinerja Karyawan dapat dipengaruhi secara tidak signifikan oleh Total Quality Management*Kepuasan Kerja atau dengan meningkatkan Total Quality Management*Kepuasan Kerja maka Kinerja Karyawan akan mengalami peningkatan yang rendah. Sehingga Kepuasan Kerja merupakan variabel moderasi yang semu.

Dari hasil keseluruhan dapat disimpulkan bahwa variabel bebas mempunyai pengaruh yang signifikan terhadap Kinerja Karyawan secara simultan dan parsial. Dan dari sini dapat diketahui bahwa ketiga variabel bebas tersebut yang paling dominan pengaruhnya terhadap Kinerja Karyawan adalah Total Quality Management karena memiliki nilai koefisien beta dan t hitung paling besar.

\section{PENUTUP}

Penelitian ini dilakukan untuk mengetahui pengaruh Total Quality Management (X1) terhadap Kinerja Karyawan (Y) dengan variabel moderating yaitu Kepuasan Kerja (X2). Adapun kesimpulan dari hasil analisis data adalah (1) Total Quality Management mempunyai pengaruh yang signifikan terhadap Kinerja Karyawan sehingga dengan semakin meningkatkan nilai Total Quality Management (TQM) maka akan memberikan peningkatan yang signifikan terhadap Kinerja Karyawan. (2) Total Quality Management dan Kepuasan Kerja menunjukkan pengaruh yang tidak signifikan terhadap Kinerja Karyawan, maka hipotesis yang menyatakan bahwa Kepuasan Kerja memoderasi terhadap hubungan antara Total Quality Management dan Kinerja Karyawan secara semu karena pengaruhnya tidak signifikan.

Berdasarkan kesimpulan di atas, diharapkan pihak perusahaan dapat mempertahankan serta meningkatkan Total Quality Management, karena variabel Total Quality Management mempunyai pengaruh dalam mempengaruhi Kinerja Karyawan. Mengingat variabel moderator dalam penelitian ini merupakan hal yang sangat penting dalam mempengaruhi Kinerja Karyawan namun masih semu, diharapkan hasil penelitian ini dapat dipakai sebagai acuan bagi peneliti selanjutnya untuk mengembangkan penelitian ini dengan mempertimbangkan variabel-variabel lain yang merupakan variabel lain diluar variabel yang sudah masuk dalam penelitian ini.

\section{DAFTAR PUSTAKA}

Akdere, M. (2009). A multi-level examination of quality-focused human resource practices and firm performance: Evidence from the US healthcare industry. International Journal of Human Resource Management. https://doi.org/10.1080/09585190903142399

Al-Shobaki, S. D., Fouad, R. H., \& Al-Bashir, A. (2010). The Implementation of Total Quality Management ( TQM ) for The Banking Sector in Jordan. 
Jordan Journal of Mechanical and Industrial Engineering. https://doi.org/10.5296/ijim.v1i1.771

ALNasser, A., Yusoff, R. Z., \& Islam, R. (2013). Relationship between hard total quality management practices and organizational performance in municipalities. American Journal of Applied Sciences. https://doi.org/10.3844/ajassp.2013.1214.1223

Alsughayir, A. (2014). Does Practicing Total Quality Management Affect Employee Job Satisfaction in Saudi Arabian Organizations? European Journal of Business and Management www.iiste.org ISSN.

Chang, C. C., Chiu, C. M., \& Chen, C. A. (2010). The effect of TQM practices on employee satisfaction and loyalty in government. Total Quality Management and Business Excellence. https://doi.org/10.1080/14783363.2010.530796

Culbertson, S. S. (2011). Do Satisfied Employees Mean Satisfied Customers? Academy of Management Perspectives. https://doi.org/10.5465/amp.2009.37008005

Eddy, P. (2006). Pengaruh Kreativitas Dan Kerjasama Tim Terhadap Kinerja Manajer Pada PT.

Jesslyn K Cakes Indonesia Cabang Surabaya. Jurnal Ilmu-Ilmu Ekonomi.

Efendi, P., \& Mandala, K. (2018). Pengaruh Implementasi Total Quality Management Terhadap Kepuasan Pelanggan Pada Perusahaan Barjaz Di Denpasar. E-Jurnal Manajemen Universitas Udayana. https://doi.org/10.24843/ejmunud.2018.v7.i03.p19

Enny W., M. (2015). Effect of ISO 900-2008 QMS, Total Quality Management and Work Environment on Job Satisfaction and Employee Performance at PT Mount Dreams Indonesia in Gresik. The International Journal of Business \& Management.

Hameed, A., Ramzan, M., kashif zubair, hafis m, Ali, G., \& Arslan, M. (2014). Impact of compensation on employee performance. International Journal of Business and Social Science. https://doi.org/10.1007/s13398-014-01737.2

Joiner, T. A. (2007). Total quality management and performance. International Journal of Quality \& Reliability Management. https://doi.org/10.1108/02656710710757808

Kamal, R., \& Sengupta, D. (2008). A Study of Job Satisfaction of Bank Officers Objectives of the Study. Prajnan.

Khan, A. H., Nawaz, M. M., Aleem, M., \& Hamed, W. (2012). Impact of job satisfaction on employee performance: An empirical study of autonomous Medical Institutions of Pakistan. African Journal of Business Management. https://doi.org/10.5897/AJBM11.2222

Ooi, K. B., Bakar, N. A., Arumugam, V., Vellapan, L., \& Loke, A. K. Y. (2007). Does TQM influence employees' job satisfaction? An empirical case analysis. International Journal of Quality and Reliability Management. https://doi.org/10.1108/02656710710720330

Ooi, K. B., Lin, B., Tan, B. I., \& Chong, A. Y. L. (2011). Are TQM practices supporting customer satisfaction and service quality? Journal of Services Marketing. https://doi.org/10.1108/08876041111161005

Prasanti, A. P., \& Damayanti, N. A. (2018). Pengaruh Penerapan Prinsip Leadership, Employee Involvement, dan Continuous Improvement terhadap Kepuasan Kerja Karyawan. Jurnal Administrasi Kesehatan Indonesia. https://doi.org/10.20473/jaki.v3i2.2015.118-128

Pratama, A. A. N., \& Maghfiroh, F. N. (2018). Pengaruh Total Quality Management (TQM) terhadap Kinerja Karyawan di BMT Taruna Sejahtera Ungaran, Jawa Tengah. Muqtasid: Jurnal Ekonomi Dan Perbankan Syariah. https://doi.org/10.18326/muqtasid.v7i1.93-117

Pritchard, R. D., \& Karasick, B. W. (1973). The effects of organizational climate on managerial job performance and job satisfaction. Organizational 
Behavior and Human Performance. https://doi.org/10.1016/00305073(73)90042-1

Pushpakumari, M. (2008). The impact of job satisfaction on job performance: An empirical analysis. In City Forum.

Putu, N., Juana, P., Sudibya, I. G. A., \& Sintaasih, D. K. (2016). 9001: 2008 Terhadap Kinerja Pegawai Dengan Mediasi Kepuasan Kerja, 21(1), 92-101.

Satyawati, N. M. R., \& Suartana, i W. (2014). Pengaruh Gaya Kepemimpinan dan Budaya Organisasi terhadap Kepuasan Kerja yang Berdampak pada Kinerja Keuangan. E-Jurnal Akuntansi.

Schroeder, R. G., Linderman, K., \& Zhang, D. (2010). Evolution of Quality: First Fifty Issues of Production and Operations Management. Production and Operations Management. 5956.2005.tb00234.x https://doi.org/10.1111/j.1937- 